\begin{tabular}{l|c|c}
\hline ISSN: 0001-5113 & ACTA ADRIAT., & ORIGINAL SCIENTIFIC PAPER \\
AADRAY & $62(2): 149-158,2021$ & \\
\hline
\end{tabular}

\title{
Histological structure and histochemical composition of the digestive tract of salema porgy, Sarpa salpa (Linnaeus, 1758) (Teleostei: Sparidae)
}

\author{
Judita OZRETIĆ ${ }^{1}$, Nives KEVIĆ ${ }^{1}$, Ivana RESTOVIĆ ${ }^{2}$ and Ivana BOČINA ${ }^{1, *}$ \\ ${ }^{1}$ Faculty of Science, Department of Biology, University of Split, \\ Ruđera Boškovića 33, 21000 Split, Croatia \\ ${ }^{2}$ Faculty of Humanities and Social Sciences, University of Split, \\ Poljička cesta 35, 21000 Split, Croatia \\ *Corresponding author: e-mail: bocina@pmfst.hr
}

The histological structure and histochemical characteristics of the digestive tract of five specimens of salema porgy (Sarpa salpa, L.) were analysed using haematoxylin-eosin, Alcian blue/PAS and orcein-Giemsa staining techniques. The digestive system of salema porgy consists of esophagus, stomach and intestines with associated organs such as liver, pancreas and gallbladder. The wall of esophagus, stomach, intestines and gallbladder has four distinctive layers: the mucosa, the submucosa, the muscular and outer layer, serosa or adventitia. The mucosa consists of two different layers: epithelium and lamina propria. Mucosa of the upper part of the digestive system is layered by single squamous epithelium, while those of lower part of the digestive system is layered by single columnar epithelium. The submucosa is a layer made of connective tissue and blood vessels. In most parts of the digestive system the muscular layer consists of two parts: circular and longitudinal. The exception is the muscular layer of the stomach fundus which has three layers: inner, medium and outer. The outermost layer in the esophagus is adventitia made of connective tissue, blood vessels and nerves. In the stomach, intestines and the gallbladder this layer is replaced by serosa. Histochemical analysis has shown that mucosal cells in all parts of the digestive tube contain acid mucopolysaccharides (MPS). The liver consists of hepatocytes separated by sinusoidal capillaries. The pancreatic tissue is scattered along the liver parenchyma and along the wall of pyloric caeca. The present study is the first record on digestive system histology of salema porgy showing that it is congruent to its feeding habits.

Key words: histoarchitecture; histochemistry; Sarpa salpa L.; digestive system 


\section{INTRODUCTION}

The salema porgy Sarpa salpa (Linnaeus, 1758) belongs to the Sparidae family. It can be found in Eastern Atlantic, in the Mediterranean, the Black sea, and in the western part of the Indian Ocean (SAHINYILMAZ \& YIGIT, 2018; FROESE \& PAULY, 2019). In the Adriatic Sea the salema porgy could be found along the coast from the shallows to depths of $70 \mathrm{~m}$. It resides on rocky and sandy bottoms covered with algae. Salema porgy has an age-related mixed diet: juveniles are plankton feeders while young and adults are herbivorous with diet ranging from full algal to mixed algal-seagrass-epiphytes to full seagrass consumption (HAVELANGE et al., 1997). Due to its algal and seaweed diet salema porgy was also reported as a fish causing ichthyoallyeinotoxism, a rare kind of food poisoning contracted following the ingestion of fish (DE HARO \& POMMIER, 2006). NEOFITOU (2016) reported that in the Mediterranean salema aggregates around floating cage farms feeding on waste from fish farms of seabass and seabream as well. As in other vertebrates, in fish the digestive tract is made of alimentary canal, a hollow tube which is longitudinally divided into the esophagus, the stomach, the intestines and the rectum (TREER et al., 1995). Organs, such as tongue, teeth, liver, pancreas and gallbladder, are associated to the alimentary tube. Although the salivary glands are usually missing in the oral cavity of fish (TREER et al., 1995), mucosal epithelium of the alimentary tube in fishes as well as in other vertebrates usually contains mucous cells with different histochemical features (FERRI et al., 2001) Content inside the mucous cells depends on different types of mucopolysaccharides (MPS) and it is usually in correlation with species, age, regions of the alimentary tract and feeding habits of the fish (PARK \& KIM 2001; SARASQUETE et al., 2001; CAO \& WANG, 2009; DAS NEVES CARDOSO et al., 2015). In most fish intestinal mucous cells contain acidic MPS (CATALDI et al., 1987; ALABDULHADI, 2005; BOČINA et al., 2016). The quality and quantity of the mucus from the intestinal goblet cells could be correlated to environmental pollution as well (FERRANDO et al., 2006). Histo- logically, from the cranial end of the esophagus to the caudal end of the rectum the wall of the digestive tube consists of four distinctive layers: the mucosa, the submucosa, the muscularis externa and the serosa or adventitia (MESCHER, 2013). The digestive system of fish usually shows a remarkable diversity of morphological and functional features, particularly in connection with special nutritional behavior, body shape and sex (KAPOOR et al., 1975; DÍAZ et al., 2008; DAS NEVES CARDOSO et al., 2015). Morphological studies could be of great help for understanding the relationship between physiological, biochemical and molecular mechanisms (KALHORO et al., 2018). Even in aquaculture, anatomical and histological characteristic of the fish digestive system could help to elucidate the development of pathological conditions, to improve nutritional formulations and thus promote the feed management (KALHORO et al., 2018). Although salema porgy has been a subject of research studies, especially those concerning its feeding habits, adaptation and growth as well as its intestinal histochemical distribution of digestive enzymes (HAVELANGE et al., 1997; KOZARIĆ et al., 2006, SAHINYILMAZ \& YIGIT, 2018), the aspects of its histological features of the digestive system as a whole were lacking. Thus, the aim of this study was to elucidate the morphology of the digestive system and histochemical features of the mucins secreted by the epithelial mucous cells of the digestive tract of salema porgy.

\section{MATERIALS AND METHODS}

Five adult specimens of salema porgy were used as samples for this study. The samples were caught nearby the Island of Hvar, Croatia in February 2019. The average length of collected samples was $20.65 \mathrm{~cm}$ and average weight $121.08 \mathrm{~g}$. After collecting, parts of the digestive system (oesophagus, stomach, intestines, liver, pancreas and gallbladder) were fixed in $10 \%$ formalin. Tissue sections were then dehydrated in the ascending series of ethanol, cleared with xylene and embedded in paraffin. Six micrometers thick transversally cut tissue samples were mounted on glass slides. To present basic mor- 
phology of the digestive system, after deparaffinization in xylene, tissue samples were stained with haematoxylin-eosin (H\&E) (Hematoxylin M, BioGnost, Croatia; Eosin Y $1 \%$ aqueous, BioGnost, Croatia) staining (BOČINA et al., 2016; BOČINA et al., 2017). Alcian blue/PAS (AB/PAS) technique was used to observe histochemical composition of mucosal cells while OrceinGiemsa staining techniques was used to see whether there are some elastic fibers in the wall of salema porgy's digestive system. The sections were observed using a light microscope Zeiss Axioskop.

\section{Alcian blue/PAS staining}

$\mathrm{AB} /$ PAS staining was used in order to establish the histochemical nature of mucins secreted by the goblet cells in salema porgy's digestive tube. The sections were deparaffinized first and then were brought to distilled water through downgraded ethanol series and oxidized in 1\% aqueous periodic acid (Periodic Acid, VWR Chemicals, Belgium) solution for 15 minutes at room temperature. After washing in distilled water, the sections were immersed in Schiff's reagent for $45 \mathrm{~min}$ and washed again in water. The sections were then immersed in $1 \% \mathrm{AB}$ (Alcian Blue 8GX, ThermoFisher, Germany) in $3 \%$ acetic acid $(\mathrm{pH} \mathrm{2.5)}$ for $45 \mathrm{~min}$. Then the slides were finally washed in running tap water, dehydrated through ascending series of ethanol, cleared in xylene and mounted in mounting medium for microscopy (Neo-Mount, Merck, Germany). The sections were dehydrated, cleared and mounted on glass slides (BEBIĆ et al., 2020).

\section{Orcein-Giemsa staining}

Orcein-Giemsa staining (Orcein, Sigma Aldrich, Missouri, USA; Giemsa, T.T.T., Croatia) was used to observe the presence of elastic fibers in the tissue samples. Deparaffinized tissue samples were stained with orcein for an hour. After rinsing in tap water for 15 minutes, samples were left in Giemsa solution overnight. Next day the tissue samples were stained with eosin for 2 minutes, dehydrated, cleared and mounted on glass slides (PAVELIN et al., 2018).

\section{RESULTS}

\section{The oesophagus}

The oesophagus in salema porgy is a straight tube of average length of $4.2 \mathrm{~cm}$ (Fig. 1A and 1B). The oesophageal wall of the salema porgy Sarpa salpa L. consists of four layers: mucosa (tunica mucosa), submucosa (tunica submucosa), muscular layer (tunica muscularis) and the outer layer (tunica adventitia). Mucosa

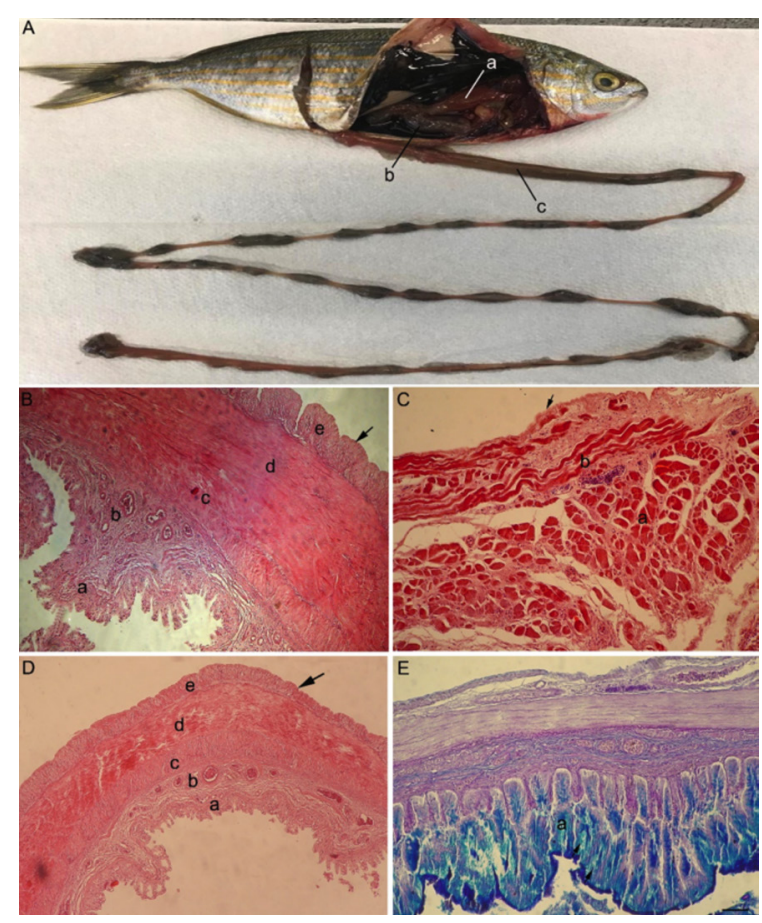

Fig. 1. A) Anatomy of the digestive tract of the salema porgy Sarpa salpa, L.: a-oesophagus; $b$ - stomach; $c$-intestines. B) Cross section through the oesophagus: $a$ - mucosa; $b$ - submucosa; $c$ - inner muscular layer; $d$-middle muscular layer; $e$-outer muscular layer; (arrow) - external layer, adventitia. $H \& E, 10 x$. C) Cross section through the muscular layer of the oesophagus: $a$-longitudinal fibers; $b$-circular fibers (cross striated); (arrow) - adventitia. H\&E, 40x. D) Cross section through the stomach of salema porgy: $a$ - mucosa; $b$-submucosa; $c$ - inner muscular layer; $d$ - middle muscular layer; e - outer muscular layer; (arrow) - external layer (serosa). $H \& E, 10 x$. E) Cross section through the stomach: a-mucosa; (arrows) cells containing acid MPS. AB/PAS, 20x. Scale bar = $1 \mathrm{~cm}$ 
and submucosa form folds which enter deeply into the oesophageal lumen. The mucosa is lined with single layered squamous epithelium. Mucosal lamina propria consists of tightly packed tubular glands which do not show positive staining to AB/PAS method. Glandular cells are relatively round in shape with dark nuclei placed at the basal side of the cell and a light, distinctly granular cytoplasm which indicates the enzyme production of these cells (Fig. 1B). Submucosa protrudes deeply into the folds, it is made of dense connective tissue rich in blood vessels Muscular layer of oesophagus is made of three layers: inner and outer layer were made of longitudinal muscle fibers while the middle layer was made of circular muscle fibers. Muscle fibers are cross-striated pointing that the oesophageal muscular layer is made of skeletal muscle fibers (Fig. 1C). Outer layer is tunica adventitia formed of connective tissue containing blood vessels. No elastic fibers were found in the oesophageal wall.

\section{The stomach}

\section{Fundus}

The salema porgy's stomach is placed between the oesophagus and intestines. It is a sac like organ of average length of $3.75 \mathrm{~cm}$. The stomach fundic wall has four distinctive layers: the mucosa, the submucosa, the muscular layer and the outer layer in the form of serosa (Fig. 1D). Fundic mucosa creates shallower folds but it is similar to those of oesophagus. The epithelium of the mucosa consists of the single layered squamous cells. Lamina propria also has the tubular glands similar to those of the oesophagus. The lamina propria of the oesophagus is much thicker than those of the stomach. The submucosa is made out of relatively dense connective tissue with numerous blood vessels. Muscular layer of the stomach fundus is very developed. It consists of three layers: inner, middle and outer one. All three layers were made of smooth muscle cells. Using AB/PAS technique mucosa stains distinctly blue which indicates the presence of acid MPS in the cells of gastric glands (Fig. 1E). Orcein staining did not show the presence of the elastic fibers in the connective tissue of the fundic wall.

\section{Pylorus}

The wall of the pyloric region of the stomach consists of mucosa, submucosa, muscular layer and outer layer. Mucosa is lined with single layered columnar epithelium with microvilli (Fig. 2A). Because of the large quantity of detritus in the stomach lumen the mucosal integrity is impaired. Goblet cells are spread between the columnar epithelial cells and they stain blue when treated with $\mathrm{AB} / \mathrm{PAS}$ which indicates the presence of the acid MPS (Fig. 2B). Submu-

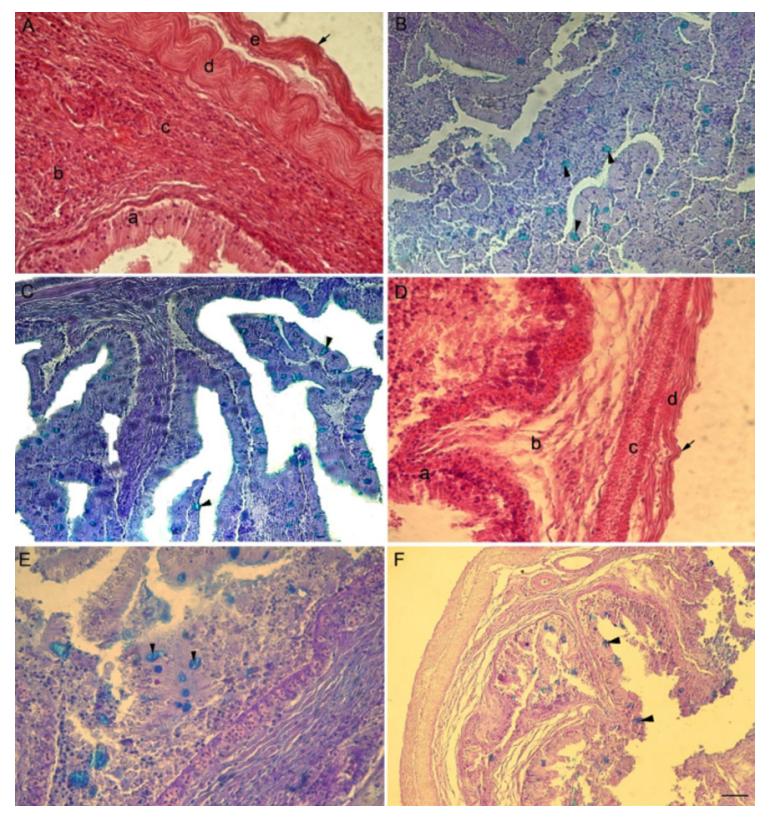

Fig. 2. A) Cross section through the pyloric region of the stomach: a - simple columnar epithelium with microvilli; $b$ - lamina propria; c - submucosa; $d$ - inner muscular layer; e-outer muscular layer; (arrow) - serosa. H\&E, 40x. B) Goblet cells containing acid MPS in the pyloric mucosa (arrowheads). AB/PAS, 10x. C) Mucosal goblet cells in the pyloric caeca containing acid MPS (arrowheads). AB/PAS, 10x. D) Cross section trough the anterior intestines: a - mucosa; $b$ - submucosa; c-inner muscular layer; $d$-outer muscular layer; (arrow) - serosa. H\&E, 20x. E) Goblet cells in the mucosa of the anterior intestines: blue colour indicates acid MPS (arrowheads). AB/PAS, 40x. F) Cross section through the middle intestines. Goblet cells containing acid MPS (arrowheads). AB/PAS, 20x. Scale bar $=1 \mathrm{~cm}$ 
cosa is similar to those in the stomach fundus. Muscular layer of the pyloric region consists of smooth muscle cells organized in two layers: inner circular and the outer longitudinal layer. Outer layer of pylorus is serosa made of single layered mesothelium. No elastic fibers were found using orcein staining technique in the connective tissue of the pyloric region.

\section{Pyloric caeca}

In salema porgy there are four pyloric caeca in the pyloric region of the stomach. By its histology the wall of the pyloric caeca is identical to those in the pylorus of the stomach. Mucosa is lined with single layered columnar epithelium with microvilli. Goblet cells are scattered among columnar cells. When treated with $\mathrm{AB} / \mathrm{PAS}$ the goblet cells stained blue indicating the presence of the acid MPS (Fig. 2C). Orcein staining did not show the presence of any elastic fibers in the connective tissue of pyloric caeca.

\section{The intestines}

Since the salema porgy is herbivorous fish, its intestines are very long (average length of intestines in collected samples was $92 \mathrm{~cm}$ ) therefore they were dissected into four parts: anterior, middle, posterior and the final part of the intestines (rectum). The wall of all the parts of the intestines consists of four layers: mucosa, submucosa, muscular layer and the serosa (Fig. 2D). The mucosa is covered with the single layered columnar epithelium with microvilli. Numerous goblet cells containing acid MPS could be seen in the intestinal epithelium when treated with AB/PAS technique (Fig. 2E). Integrity of the epithelium of the intestines was impaired because of the large quantity of detritus. In the middle part of the intestines, mucosa forms shallow folds while in the posterior intestines mucosal folds are higher which make the posterior intestines wall much thicker than in the upper parts of the intestines. AB/PAS staining in the middle intestines' mucosa have shown positive reaction to acid MPS (Fig. 2F). In the posterior intestines positive reaction to $\mathrm{AB} / \mathrm{PAS}$

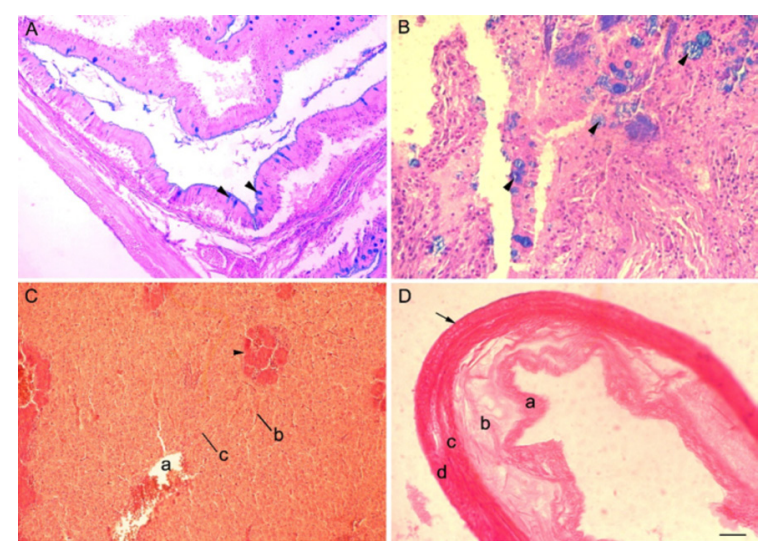

Fig. 3. A) Cross section through posterior intestines. Note goblet cells with acid MPS (arrowheads). AB/PAS, $20 x$. $B)$ Cross section through the final (part of the intestines: goblet cells with acid MPS 8arrowheads). AB/ $P A S, 40 X . C)$ Cross section through liver parenchyma: $a$ - central vein; $b$ - sinusoid capillaries; $c$ - hepatocytes; endocrine portion of pancreas (arrowheads). $H \& E, 20 x . D)$ Cross section through the gallbladder: a- mucosa; $b$-submucosa; c-inner muscular layer; $d$-outer muscular layer; (arrow) - serosa. H\&E, 40x. Scale bar $=1 \mathrm{~cm}$

staining can be noticed even in the region of microvilli (Fig. 3A). The lamina propria in the posterior intestines is a scarce layer of dense connective tissue which continues into the loose connective tissue of submucosa. The connective tissue of both mucosa and submucosa is rich with blood vessels. In the final part of the intestines connective tissue of lamina propria which continues into the submucosa and contains numerous blood vessels. The mucosa of the final part of the intestines (rectum) has also shown positive reaction to acid MPS when treated with AB/PAS (Figure 3B). Submucosa of the anterior and middle intestines consists of loose connective tissue containing lots of blood vessels. The muscular layer in the whole intestines is made of two layers but in the anterior intestines the inner layer is longitudinal in arrangement, and outer is circular, while in the middle intestines the inner is oblique and the outer is longitudinal. In both posterior and final part of the intestines inner muscular layer is circular and the outer layer is longitudinal. In the final part of the intestines the two muscular layers are much wider than in the upper parts and the inner layer makes a strong sphincter. The outer layer of the intestines is 
formed by single layered squamous epithelium, mesothelium. Orcein staining did not show the positive reaction to elastic fibers in any part of the intestines.

\section{The liver and the pancreatic tissue}

The liver of the salema porgy consists of three lobes. The liver parenchyma is made of tightly packed liver cells (hepatocytes). Lines of hepatocytes are divided by sinusoid capillaries which infuse into the central vein (Fig. 3C). Pancreatic tissue is scattered across the liver parenchyma and it is formed of columnar cells with centrally positioned nuclei (Fig. 3C). The pancreatic cells are usually located around the blood vessels. Pancreatic tissue can be seen on the sections through the pyloric caeca too. In this region numerous pancreatic cells located around major blood vessels can be noticed along the wall of pyloric caeca. It seems that these pancreatic cells form endocrine portions of the pancreatic tissue since pancreatic cells in the liver parenchyma as well as in the region of pyloric caeca did not contain granules in their cytoplasm and they are usually located around blood vessels. AB/PAS staining did not show positive staining in the tissue of liver and pancreas.

\section{The gallbladder}

The wall of the salema porgy gallbladder is made of mucosa, submucosa, muscular layer and the outer layer (serosa). Mucosa is covered with single layered columnar epithelium. Connective tissue of lamina propria continues into the loose connective tissue of submucosa. Muscular layer is made of smooth muscle cells organized in two layers: inner circular, and outer longitudinal layer (Figure 3D). Both $\mathrm{AB} / \mathrm{PAS}$ and orcein staining did not show positive reaction.

\section{DISCUSSION}

The digestive system of vertebrates consists of the digestive tube and the associated organs such as pancreas, liver and gallbladder (STE-
VENS \& HUME, 1995). The digestive tube usually consists of oesophagus, stomach and intestines although in some fishes such as Cyprinidae, Labridae and Gobiidae the stomach has evolutionary disappeared (AL-HUSSAINI, 1949; BARTON, 2006). In spite of this it seems that this loss does not influence the digestion, as the stomachless fish can be either herbivorous or carnivorous. The herbivorous fishes usually have relatively long guts, whereas in carnivorous fishes the guts are generally shorter than their body length (BUDDINGTON et al., 1997; HORN et al., 2006; GERMAN et al., 2010).

The oesophagus of teleost fish, as with most vertebrates, serves to transport food and it is usually lined with stratified squamous epithelium with cells which secrete mucus (CATALDI et al., 1987; ABDULHADI, 2005; NAZLIĆ et al., 2014; BOČINA et al., 2016). The oesophagus of salema porgy, as shown in this study, is also layered with squamous epithelium but single layered. In common eel (Anguilla etallot) and fresh water stingray (Himantura etalloth) oesophageal mucosa is lined with stratified columnar epithelium (CLARKE \& WITCOMB, 1980; DOMENEGHINI et al., 2005; CHATCHAVALVANICH et al., 2006). The oesophageal mucosa of salema porgy also contains tubular glands in the lamina propria. Submucosa is made of loose connective tissue rich with blood vessels. As with other fish the muscular layer consists of inner longitudinal and outer circular muscle layers which are made of striated muscular tissue (BOGUT et al., 2006).

The stomach of vertebrates is a sack like muscular organ which is separated from oesophagus and intestines by sphincters, and is characterized by specialized cells which produce hydrochloric acid and pepsin (STEVENS \& HUME, 1995; SMITH et al., 2000). Histology of the fish stomach mucosa is usually simpler than the histology of the stomach mucosa of higher vertebrates (ARELLANO et al., 2001). According to BOGUT et al. (2006) the stomach wall of the fish consists of three layers: mucosa, muscular layer and serous layer. But according to present data on species Sparus aurata (CATALDI et al., 1987), Merluccius merluccius (BOČINA et al., 2016), Scorpena porcus (NAZLIĆ et al., 2014) as well as on salema porgy 
(Sarpa salpa) stomach wall was found to be made of four layers: mucosa, submucosa, muscular layer and serosa. The stomach wall of most fish species is lined by columnar epithelium with gastric glands which are mostly placed in the pyloric region of the stomach (CLARKE \& WITCOMB, 1980; CATALDI et al., 1987; NAZLIĆ et al., 2014; DAS NEVES CARDOSO et al., 2015; BOČINA et al., 2016; BEBIĆ et al., 2020). On the other hand, in salema porgy a stomach mucosa in the fundic part is lined with single layered squamous epithelium similar to the one described in the oesophagus and the lamina propria of the stomach consists of tubular glands with cells containing acid MPS. Pyloric part of the stomach in salema porgy is also lined with single layered columnar epithelium with microvilli and goblet cells containing acid MPS.

At the beginning of the intestines there are four pyloric caeca which are histologically similar to the stomach pylorus. The fish intestines are usually divided into proximal and distal parts (ABDULHADI, 2005; CHATCHAVALVANICH et al., 2006; DAI et al., 2007; BEBIĆ et al., 2020). The intestines wall of the fish in general consists of three layers: mucosa, muscular layer and serous layer (BOGUT et al., 2006; NAZLIĆ et al., 2014; BOČINA et al., 2016). Since salema porgy is herbivorous fish its intestines are very long and can be divided anatomically into anterior, middle, posterior and the final part of the intestines. All along the length of the intestines four different layers could be distinguished: mucosa, submucosa, muscular layer and serosa. The same was described in some other fishes (PAVELIN et al., 2018; BOČINA et al., 2017; BEBIĆ et al., 2020). Intestinal mucosa of salema porgy is lined with single layered columnar epithelium with microvilli and goblet cells with acid MPS previously described in some other fishes (ABDULHADI, 2005; KOZARIĆ et al., 2006; PAVELIN et al., 2018; BOČINA et al., 2016). The mucosa of the upper intestines in garfish Belone belone contains goblet cells with neutral MPS, whereas in the lower intestine goblet cells contain acid MPS (BOČINA et al., 2017). According to KOZARIĆ et al. (2006) different parts of salema porgy intestines play different parts in food digestion and absorption, so intestinal digestion and absorption of nutrients occur mainly in the anterior and middle parts of the intestines while the final part of the intestines plays a major role in protein digestion.

As in other vertebrates the liver of salema porgy consists of hepatocytes arranged in regular plates surrounding central vein and separated between each other by sinusoid capillaries. In fishes the pancreatic tissue is spread along intestine or pyloric caeca or across the liver tissue (CATALDI et al., 1987; BOČINA et al., 2016). In salema porgy pancreatic tissue is spread across the liver parenchyma as well as along the wall of pyloric caeca. It seems that in salema porgy pancreatic tissue usually surrounds blood vessels representing probably the endocrine portions of pancreatic tissue which could also be found in some other fishes (BISHOP \& ODENSE, 1966; CLARKE \& WITCOMB, 1980; BEBIĆ et al., 2020).

In conclusion, the present study represents the first record on salema porgy's Sarpa salpa digestive system histology and histochemistry. The data obtained by present study have shown that salema porgy has a long digestive tube which is common feature of all herbivorous fish. As was expected, the histoarchitecture of digestive tube in salema porgy is similar to those of other herbivorous fish containing mucosal, submucosal, muscular and outer layer. Data obtained by histochemical analysis have shown that acid mucopolysaccharides were mostly present in the salema porgy's digestive system. The histology and histochemical composition of the salema porgy's digestive system seem to be as usual as in other herbivorous fishes and in accordance with its feeding habits.

\section{ACKNOWLEDGMENTS}

This work was supported by Ministry of Science, Education and Sports of the Republic of Croatia support (I. Bočina). 


\section{REFERENCES}

AL-ABDULHADI, H.A. 2005. Some comparative histological studies on alimentary tract of tilapia fish (Tilapia spilurus) and sea bream (Mylio cuvieri). Egypt. J. Aquat. Res., 31: 387-397.

AL-HUSSAINI, A.H. 1949. On the functional morphology of the alimentary tract of some fish in relation to differences in their feeding habits: Anatomy and histology. Q. J. Microsc. Sci., 90: 109-139.

ARELLANO, J.M., V. STORCH \& C. SARASQUETE. 2001. Histological and histochemical observations in the stomach of the Senegal sole, Solea senegalensis. Histol. Histopathol., 16: 511-521. https://doi.org/10.14670/HH-16.511.

BARTON, M. 2006. Bond's biology of fishes, third ed. Thomson Brooks, California, 912 pp.

BEBIĆ, M., N. KEVIĆ, I. RESTOVIĆ, M. ŠANTIĆ \& I. BOČINA. 2020. Histological and histochemical studies of digestive system in the megrim, Lepidorhombus whiffiagonis (Teleostei: Scophthalmidae). Iran. J. Ichthyol., 7: 125135. http://dx.doi.org/10.22034/iji.v7i2.372.

BISHOP, C. \& P ODENSE. 1966. Morphology of the digestive tract of the cod, Gadus morhua. J. Fish. Res. Board. Can., 23: 1607-1615. https://doi.org/10.1139/f66-149.

BOČINA, I., S. RUŽIĆ, I. RESTOVIĆ \& A. PALADIN. 2016. Histological features of the digestive tract of the adult European hake Merluccius merluccius (Pisces: Merlucciidae). Ital. J. Zool., 83: 26-33. https://doi.org/10.1080/11250 003.2015.1113311.

BOČINA, I., Ž. ŠANTIĆ, I. RESTOVIĆ \& S. TOPIĆ. 2017. Histology of the digestive system of the garfish Belone belone (Teleostei: Belonidae). Eur. Zool. J., 84: 89-95. https://doi.org/10.1080 /11250003.2016.1276977.

BOGUT, I., D. NOVOSELIĆ \& J. PAVLIČEVIĆ. 2006. Biologija riba (Fish biology). J.J. Strossmayer University of Osijek, University of Mostar, $587 \mathrm{pp}$.

BUDDINGTON, R.K., A. KROGDAHL \& A.M. BAKKEMCKELLEP. 1997. The intestines of carnivorous fish: Structure and functions and the relations with diet. Acta Physiol. Scand. Suppl., 638: 67-80.
CAO, X.J. \& W.M. Wang. 2009. Histology and mucin histochemistry of the digestive tract of yellow catfish, Pelteobagrus fulvidraco. Anat. Histol. Embryol., 38: 254-261. https://doi. org/10.1111/j.1439-0264.2009.00932.x.

CARDOSO, Nd., E.M. FIRMIANO, I.D. GOMES, A.A. DO NASCIMENTO, A. SALES, F.G. ARAÚJO. 2015. Histochemical and immunohistochemical study on endocrine cells (5HT, GAS, and SST) of the gastrointestinal tract of a teleost, the characin Astyanax bimaculatus. Acta Histochem., 117: 595-604. https://doi. org/10.1016/j.acthis.2015.05.007.

CATALDI, E., S. CATAUDELLA, G. MONACO, A. ROSSI \& L. TANCIONI. 1987. A study of the histology and morphology of the digestive tract of seebream, Sparus aurata. J. Fish Biol., 30: 135145. https://doi.org/10.1111/j.1095-8649.1987. tb05740.x.

CHATCHAVALVANICH, K., R. MARCOS, J. POONPIROM, A. THONGPAN \& E. ROCHA. 2006. Histology of the digestive tract of the freshwater stingray Himantura signifier Compagno and Roberts, 1982 (Elasmobranchii, Dasyatidae). Anat. Embryol., 211: 507-518. https://doi. org/10.1007/s00429-006-0103-3.

CLARKE, A.J. \& D.M. WITCOMB. 1980. A study of the histology and morphology of the digestive tract of the common ell (Anguilla etallot). J. Fish Biol., 16: 159-170. https://doi. org/10.1111/j.1095-8649.1980.tb03695.x.

CRISCOLI, A., F. COLLOCA, P. CARPENTIERI, A. BELLUSCIO \& G. ARDIZZONE. 2006. Observation on the reproductive cycle, age and growth of the salema, Sarpa salpa (Osteichthyes: Sparidae) along the western central coast of Italy. Sci. Mar., 70: 131-138.

DAI, X., M. SHU \& W. FANG. 2007. Histological and ultrastructural study of the digestive tract of rice field eel, Monopterus albus. J. Appl. Ichthyol., 23: 177-183. https://doi.org/10.1111/ j.1439-0426.2006.00830.x.

DEHARO,L.\& P.PUMMIERI. 2006. Hallucinatory fish poisoning (ichthyoallyeinotoxism): Two case reports from the Western Mediterranean and literature review. Clin. Toxicol., 44: 185-188. https://doi.org/10.1080/15563650500514590.

DÍAZ, A.O., A.M. GARCÍA \& A.L. GOLDEMBERG. 
2008. Glycoconjugates in the mucosa of the digestive tract of Cynoscion guatucupa: a histochemical study. Acta Histochem., 110: 76-85. https://doi.org/10.1016/j. acthis.2007.08.002.

DOMENEGHINI, C., S. ARRIGHI, G. RADAELLI, G. BOSI \& A. VEGGETTI. 2005. Histochemical analysis of glycoconjugate secretion in the alimentary canal of Anguilla etallot L. Acta Histochem., 106: 477-487. https://doi. org/10.1016/j.acthis.2004.07.007.

FERRANDO, S., M. MAISANO, V. PARRINO, T. FERRANDO, L. GIROSI \& G. TAGLIAFIERRO. 2006. Gut morphology and etallothionein immunoreactivity in Liza aurata from different heavy metal polluted environments. Ital. J. Zool., 73: 7-14. https://doi. org/10.1080/11250000500502228.

FERRI, D., G.E. LIQUORI, L. NATALE, G. SANTARELLI \& G. SCILLITANI. 2001. Mucin histochemistry of the digestive tract of the red-legged frog Rana aurora. Acta histochem., 103: 225237. https://doi.org/10.1078/0065-1281-00582.

FROESE, R. \& D. PAUlY. 2019. Fish Base. World Wide Web electronic publication. http://www.fishbase.org/ (accessed August 2019)

GERMAN, D.P., B.C. NAGLE, J.M. VILLEDA, A.M. RUIZ, A.W. THOMPSON, S. CONTRERAS BALDERAS \& D.H. EVANS. 2010. Evolution of herbivory in a carnivorous clade of minnows (Teleostei: Cyprinidae): Effects on gut size and digestive physiology. Physiol. Biochem. Zool., 83: 1-18. https://doi.org/10.1086/648510.

HAVELANGE, S., G. LEPOINT, P. DAUBY \& J.M. BOUQUEGNEAU. 1997. Feeding of the Sparid fish Sarpa salpa in a seagrass ecosystem: Diet and carbon flux. P.S.Z.N.I.: Mar. Ecol., 18: 289-297.

HORN, M.H., A.K. GAWLICKA, D.P. GERMAN, E.A. LOGOTHETIS, J.W. CAVANAGH \& K.S. BOYLE. 2006. Structure and function of the stomachless digestive system in three related species of New World silverside fishes (Atherinopsidae) representing herbivory, omnivory, and carnivory. Mar. Biol., 149: 1237-1245. https://doi.org/10.1007/s00227-0060281-9.

KALHORO, H., S. TONG, L. WANG, Y. HUA, J.A. VOL-
ATIANA \& Q. SHAO. 2018. Morphological study of the gastrointestinal tract of Larimichthys crocea (Acanthopterygii: Perciformes). Zoologia, 35: 1-9. https://doi.org/10.3897/zoologia.35.e25171.

KAPOOR, B. G., H. SMITH \& I.A. VERGHINA. 1975. The alimentary canal and digestion in teleosts. Adv. Mar.Biol., 13: 109-239.

KOZARIĆ, Z., S. KUŽIR, Z. PETRINEC, E. GJURČEVIĆ \& A. OPAČAK. 2006. Histochemical distribution of digestive enzymes in intestine of goldline, Sarpa salpa L. 1758. J. Appl. Ichthyol., 22: 43-48. https://doi.org/10.1111/j.14390426.2006.00694.x.

MESCHER, A.L. 2013. Junqeira's Basic Histology. Text and Atlas, $13^{\text {th }}$ ed. The McGraw-Hill Companies Inc., New York, 480 pp.

NAZLIĆ, M., A. PALADIN \& I. BOČINA. 2014. Histology of the digestive system of the black scorpionfish Scorpena porcus L. Acta Adriat., 55: 65-74.

NEOFITOU, N. 2016. Waste feed from fish farms of the Eastern Mediterranean and attraction of wild fish. J. Geosci. Osaka City Univ., 4: 112115. https://doi.org/10.13189/ujg.2016.040503.

PARK, J.Y. \& I.S. KIM. 2001. Histology and mucin histochemistry of the gastrointestinal tract of the mud loach, in relation to respiration. J. Fish Biol., 58: 861-872. https://doi. org/10.1111/j.1095-8649.2001.tb00536.x.

PAVELIN, T., N. KEVIĆ, I. RESTOVIĆ \& I. BOČINA. 2018. Histological and biochemical features of the digestive system in the cage-reared gilthead sea bream (Sparus aurata). Int. J. Biotechnol. Recent Adv., 1: 51-56. https://doi. org/10.18689/ijbr-1000108.

SAHINYILMAZ, M. \& M. YIGIT. 2018. Adaptation, growth and bio-economic evaluation of wild caught salema (Sarpa salpa Linnaeus, 1758) juveniles in culture conditions. Indian J. Mar. Sci., 47: 694-701.

SARASQUETE, C., E. GISBERT, L. RIBEIRO, L. VIEIRA \& M.T DINIS. 2001. Glyconjugates in epidermal, branchial and digestive mucous cells and gastric glands of gilthead sea bream, Sparus aurata, Senegal sole, Solea senegalensis and Siberian sturgeon, Acipenser baeri development. Eur. J. Histochem., 45: 267278. https://doi.org/10.4081/1637. 
SMITH, D.M., R.C. GRASTY, N.A. THEODOSIOU, C.J. TABIN \& N.M. NASCONE-YODER. 2000. Evolutionary relationships between the amphibian, avian, and mammalian stomachs. Evol. Dev., 2: 348-359. https://doi.org/10.1046/j.1525142x.2000.00076.x.

STEELE, L., DARNELL, K.M., CEBRIÁN, J., SANCHEZLIZASO, J.L., 2014. Sarpa salpa herbivory on shallow reaches of Posidonia oceanica beds. Anim. Biodivers. Conserv., 37: 49-57.
STEVENS, C. \& I. HUME. 1995. Microbial fermentation and synthesis of nutrients and the absorption of end products, in Comparative physiology of the vertebrate digestive system. Cambridge University Press, New York, pp. 188-228.

TREER, T., R. SAFNER, I. ANIČIĆ \& M. LOVRINOV. 1995. Ribarstvo (Fisheries). Globus Press, Zagreb, p. 464.

Received: 31 August 2020

Accepted: 29 September 2021

\title{
Histološka struktura i histokemijske osobine probavnog sustava salpe, Sarpa salpa (Linnaeus, 1758) (Teleostei: Sparidae
}

\author{
Judita OZRETIĆ, Nives KEVIĆ, Ivana RESTOVIĆ i Ivana BOČINA* \\ *Kontakt e-pošta: bocina@pmfst.hr
}

\begin{abstract}
SAŽETAK
Histološka struktura i histokemijske karakteristike probavnog sustava salpe (Sarpa salpa, L.) istraživane su korištenjem hematoksilin-eozin, alcian plavo / PAS i orcein-Giemsa tehnikama bojenja. Probavni sustav salpe sastoji se od jednjaka, želudca i crijeva s povezanim organima poput jetre, gušterače i žučnog mjehura. Zid jednjaka, želudca, crijeva i žučnog mjehura ima četiri karakteristična sloja: sluznicu, submukozu, mišićni i vanjski sloj. Sluznica se sastoji od dva različita sloja: epitela i lamine proprije. Submukoza je sloj vezivnog tkiva s krvnim žilama. U većini dijelova probavnog sustava mišićni sloj sastoji se od dva sloja mišićnih vlakana: kružnih i uzdužnih. Izuzetak je mišićni sloj fundusa želudca koji ima tri sloja mišićnih vlakana: unutarnji, srednji i vanjski. Vanjski sloj jednjaka zove se adventitia i izrađen je od vezivnog tkiva, s krvnim žilama i živcima. U želudcu, crijevima i žučnom mjehuru ovaj sloj zamjenjuje seroza. Histokemijska analiza pokazala je da stanice sluznice u svim dijelovima probavne cijevi sadrže kisele mukopolisaharide (MPS). Jetra se sastoji od hepatocita razdvojenih sinusoidnim kapilarama. Tkivo gušterače raspršeno je duž jetrenog parenhima i duž zida piloričkih nastavaka. Ovo istraživanje je prvi zapis o histologiji probavnog sustava salpe koji pokazuje da je ona u skladu s prehrambenim navikama ispitivane ribe.
\end{abstract}

Ključne riječi: histoarhitektura; histokemija; Sarpa salpa L.; probavni sustav 